\title{
Wilbrand knee
}

Figure Anisotropic scattering imaging reveals Wilbrand knee

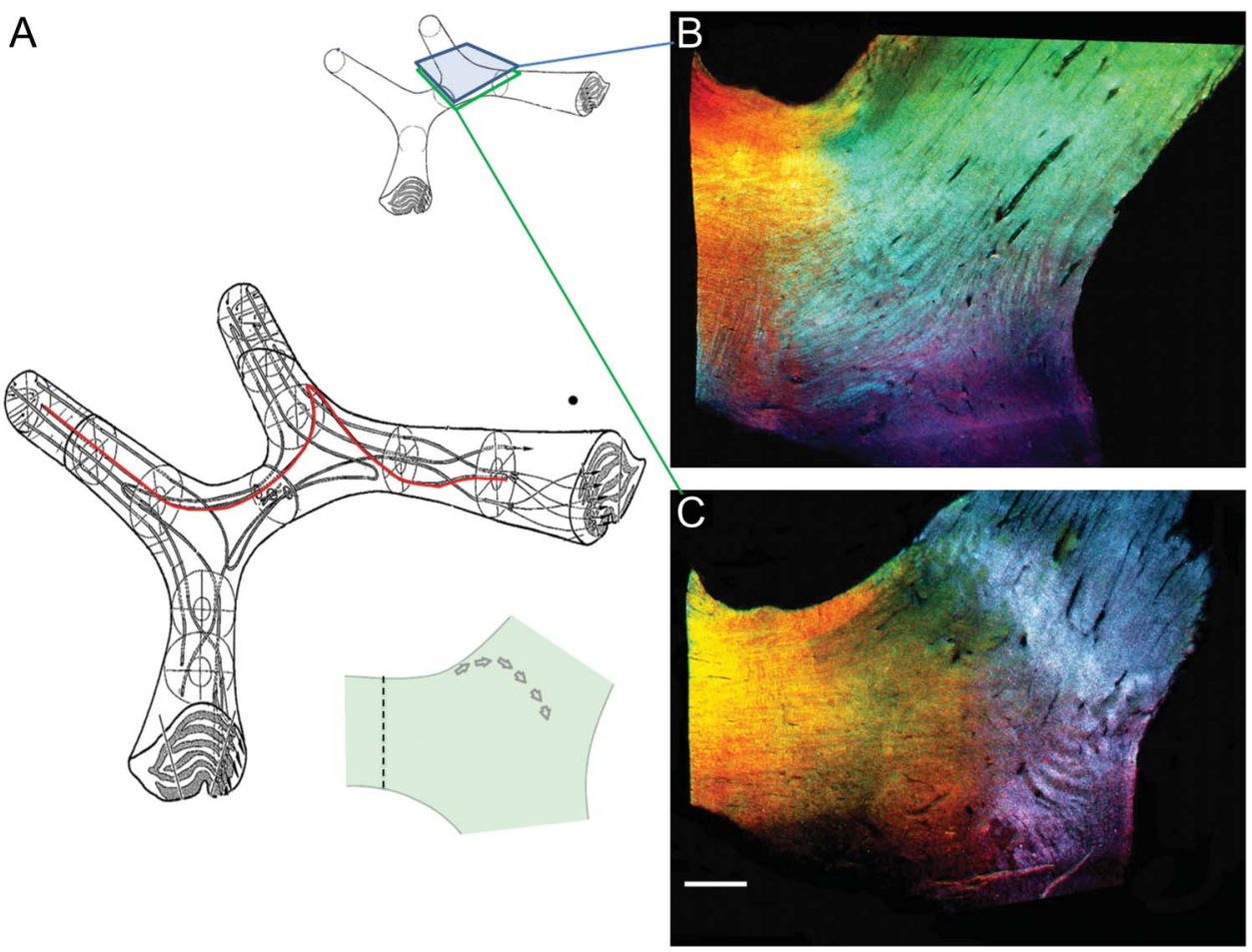

(A) Hypothetical course of Wilbrand knee indicated by red line (adapted from John P. Patten, Neurological Differential Diagnosis, 2nd ed: () 1996, Springer-Verlag, London, with kind permission of Springer Science + Business Media). (B) Superior chiasmal sections show no curving of crossing fibers. (C) Inferior chiasmal sections show sheets of crossing fibers (white) originating from the anterior chiasm that bend toward the optic nerve before arcing back toward the optic tract. Scale: $1 \mathrm{~mm}$.

Wilbrand and Saenger ${ }^{1}$ studied optic chiasms after unilateral enucleation, noting inferonasal crossing fibers curved anteriorly into the contralateral optic nerve (Wilbrand knee; figure, A). This explains contralateral superotemporal visual field defects (junctional scotomas) with optic nerve lesions at the chiasmal junction. However, Wilbrand knee may be an enucleation artifact. ${ }^{2}$ The anisotropic light-reflecting properties of myelinated axons permitted imaging of normal human chiasms. Thin sections $(25 \mu \mathrm{m})$ were illuminated and digitally imaged from 3 incident angles. Each of the images was pseudocolored (red, green, or blue) and merged, revealing an anomalously oriented fiber tract (appearing white) that reversed direction at the optic nerve-chiasm junction, found in inferior (figure, C) but not in superior sections (figure, B), consistent with Wilbrand and Saenger's original description.

Robert K. Shin, MD, Rafay A. Qureshi, Natalie R. Harris, Dara Bakar, BA, Tuo P. Li, BS, M. Samir Jafri, PhD, Cha-Min Tang, $M D, P h D$

From the University of Maryland School of Medicine (R.K.S., R.A.Q., N.R.H., D.B., T.P.L., M.S.J., C.-M.T.), Baltimore; and the Baltimore Veterans Administration Medical Center (R.K.S., R.A.Q., M.S.J., C.-M.T.), Baltimore, MD.

Author contributions: R.K. Shin contributed to the study concept and design, drafted the manuscript, assisted in revising the manuscript and figures for content, and assisted in data interpretation. R.A. Qureshi assisted in data acquisition and analysis and assisted in drafting and revising the figures. N.R. Harris assisted in data acquisition and analysis. D. Bakar assisted in data acquisition and analysis. T.P. Li contributed to the development of anisotropic scattering imaging and developed software necessary for image processing. M.S. Jafri assisted in data analysis and interpretation and assisted in drafting and revising the manuscript and figures for content. C.-M. Tang 
contributed to the study concept and design, was responsible for conceptualizing anisotropic scattering imaging and constructing the apparatus necessary to collect the data, provided oversight and supervision over data acquisition and analysis, and assisted in revising the manuscript and figures for content.

Acknowledgment: The authors thank Rainer von Coelln, MD, PhD, for his assistance in translating Wilbrand and Saenger's original case descriptions and figure legends.

Study funding: No targeted funding reported.

Disclosure: R. Shin serves as section editor (Neuro-Ophthalmology and Neuro-Otology) for Current Treatment Options in Neurology. He receives honoraria as a co-editor of the textbook Neurology for the Non-Neurologist. He has served as a consultant for Novartis and has received research support from Novartis, Teva, Biogen, and Osmotica. R. Qureshi, N. Harris, D. Bakar, T. Li, M. Jafri, and C. Tang report no disclosures. Go to Neurology.org for full disclosures.

Correspondence to Dr. Tang: ctang@som.umaryland.edu

1. Wilbrand H, Saenger A. Die Neurologie des Auges. J Bergmann 1904;3:98-120.

2. Horton JC. Wilbrand's knee of the primate optic chiasm is an artefact of mononuclear enucleation. Trans Am Ophthalmol Soc 1997;95:579-609.

\section{NeuroImages Are Free at www.neurology.org!}

All Neurology ${ }^{\circledR}$ NeuroImages can now be freely accessed on the Neurology Web site. See them at www.neurology.org, where you can also sign up for journal email alerts and check out other online features, including the Resident \& Fellow section, Neurology: Clinical Practice, and the weekly Neurology Podcasts. 


\title{
Neurology
}

\author{
Wilbrand knee \\ Robert K. Shin, Rafay A. Qureshi, Natalie R. Harris, et al. \\ Neurology 2014;82;459-460 \\ DOI 10.1212/WNL.0000000000000084
}

This information is current as of February 3, 2014

\section{Updated Information \& Services}

\section{References}

Citations

Subspecialty Collections

Permissions \& Licensing

Reprints including high resolution figures, can be found at: http://n.neurology.org/content/82/5/459.full

This article cites 2 articles, 0 of which you can access for free at: http://n.neurology.org/content/82/5/459.full\#ref-list-1

This article has been cited by 1 HighWire-hosted articles: http://n.neurology.org/content/82/5/459.full\#\#otherarticles

This article, along with others on similar topics, appears in the following collection(s):

\section{All Imaging}

http://n.neurology.org/cgi/collection/all_imaging

Optic nerve

http://n.neurology.org/cgi/collection/optic_nerve

Visual fields

http://n.neurology.org/cgi/collection/visual_fields

Visual loss

http://n.neurology.org/cgi/collection/visual_loss

Information about reproducing this article in parts (figures,tables) or in its entirety can be found online at:

http://www.neurology.org/about/about_the_journal\#permissions

Information about ordering reprints can be found online:

http://n.neurology.org/subscribers/advertise

Neurology ${ }^{\circledR}$ is the official journal of the American Academy of Neurology. Published continuously since 1951, it is now a weekly with 48 issues per year. Copyright @ 2014 American Academy of Neurology. All rights reserved. Print ISSN: 0028-3878. Online ISSN: 1526-632X.

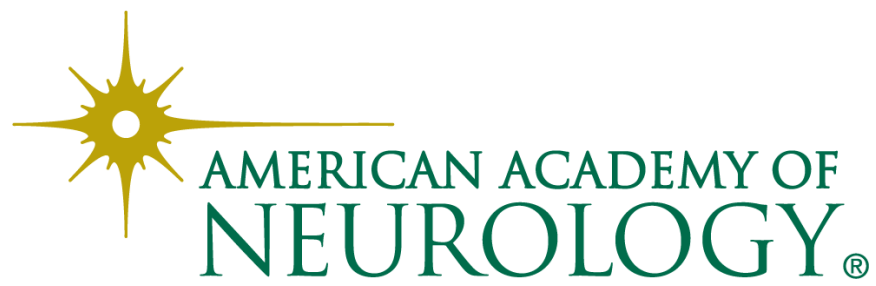

